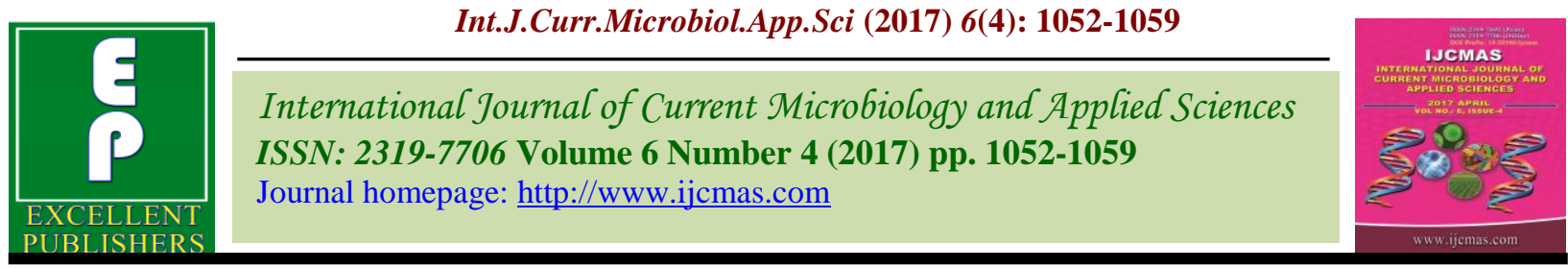

Case Study

https://doi.org/10.20546/ijcmas.2017.604.130

\title{
Factors Affecting Non-Repayment of Agricultural Loan: A Case Study of Rajasthan Marudhara Gramin Bank
}

\author{
Ritu Rathore $^{1^{*}}$, Shubham Mishra ${ }^{2}$ and Pradeep Kumar ${ }^{3}$ \\ ${ }^{1}$ Division of Dairy Economics, Statistics and Management, NDRI, Karnal, India \\ ${ }^{2}$ Department of Extension Education, MPUAT, Udaipur, India \\ ${ }^{3}$ Department of Agricultural Economics, SKNAU, Jobner, India \\ *Corresponding author
}

\begin{tabular}{|c|c|}
\hline & A B S T R A C T \\
\hline $\begin{array}{l}\text { Agricultural credit, } \\
\text { Defaulters, Bank, } \\
\text { Overdues, } \\
\text { Repayment. }\end{array}$ & \multirow{3}{*}{$\begin{array}{l}\text { This study investigated the different factors influencing the repayment of } \\
\text { agricultural credit in Jobner branch of Rajasthan Marudhara Gramin Bank. For } \\
\text { this purpose, purposive sampling was adopted and } 50 \text { borrowers were selected } \\
\text { from the list of defaulter borrowers from the branch. Through the pre-tested } \\
\text { schedules, necessary informations were collected from the defaulters as well as } \\
\text { from the bank employees regarding actual causes behind overdues. Finally } \\
\text { data were summarized using descriptive statistics. Results of study show that } \\
\text { low income generated by the use of loan, high living expenditure, large } \\
\text { amount of expenditure on social and other religious activities, higher interest } \\
\text { rate and low and unremunerated prices of farm produce etc. caused delay in } \\
\text { repayment of agricultural loan. }\end{array}$} \\
\hline Article Info & \\
\hline $\begin{array}{l}\text { Accepted: } \\
\text { 12 March } 2017 \\
\text { Available Online: } \\
10 \text { April } 2017\end{array}$ & \\
\hline
\end{tabular}

\section{Introduction}

Agriculture sector has a prime role in developing country like India where it holds the key of rapid economic development because of its size, potentiality for growth and capacity to transform the entire outlook of the economy. The contribution share of agriculture in GDP is 17.4 per cent in 201516. This sector provides employment to about 61 per cent county's work force.

Despite its critical importance the share of agriculture in GDP and employment work force of the nation is continuously declining. India is expected to be the most populous country of the word by 2050 if present growth rate 1.2 per cent perpetuates and in order to meet the growing needs of the expanding population, it is compelled to produce more than 200 million tonnes of food grains per year. This growth rate was made possible by the adoption of high yielding varieties, expansion in irrigation, higher use of modern inputs and development of infrastructures. So farmer require huge amount of credit to transform the agriculture into a profit oriented farm business. Looking the importance of credit in agriculture, regional rural banks were established on $2^{\text {nd }}$ October 1975 to provide small and medium term credit to the farmers especially to weaker sections of society like 
small and marginal farmers, landless labourers and rural artisans.

Besides providing sufficient agriculture credit to farmers, its proper utilization is prerequisite for development of national economy. With the rapid expansion of commercial banks' branch network in rural areas and subsequent increase in investment in agriculture sector through banks' advances, the problem of nonrecovery of loans is being aggravated. For any public sector credit institution, recovery of agricultural advances is of crucial importance as prompt and timely repayment not only ensures recycling of public fund for development but also builds-up confidence amongst the credit institution in their clientele and among the credit users in their own ability to develop. The effective performance of these institutions can be judged only when the farmer-borrowers repay their loans as and when they fall due to the farm credit agency.

As far as India is concerned, scenario of credit use is different. Credit utilization for productive purposes is limited because farmers are suffering from financial anemia. They used agricultural loans for nonagricultural purposes like home consumption, marriage ceremony and other prestige purposes and hence their burden of debt increases and ultimately they are not in a condition to repay the loan, thereby declared as loan defaulters. Therefore agricultural credit business is based not only on taking loan by the farmers but also on timely repayment by them.

Keeping this consideration in view of the above facts, the study in hand was undertaken to identify and highlight the causes of over dues or factors which are responsible for nonrepayment of agricultural credit in time and also to make recommendations for both financial institutes and government agencies.

\section{Materials and Methods}

\section{Selection of Branch}

Keeping in view the paramount importance of problem under consideration, Jobner branch of Rajasthan Marudhara Gramin Bank was selected purposively due to limitation of time resources.

\section{Selection of Borrowers}

A list of borrowers who were advanced agricultural loans for different purposes during the period of study (2006-15) was obtained from the bank branch under study. 50 farmers were selected randomly from the list of defaulter borrower farmers to examine the non-repayment of loan. These defaulterborrowers were then categorized into following three standard categories

1. Small: 1.0-2.0 hectares

2. Medium: 4.0-10.0 hectares

3. Large: More than 10.0 hectare

The selected sample of defaulter-borrowers consists of 18 small, 23 medium and 9 large farmers.

\section{Collection and Analysis of Data}

Primary data were collected through a set of designed and pre-tested schedule. Schedule was divided into two parts

(a) General information of sample defaulterborrowers related to education status, family size, age, land holding and family net income related data were collected to know background and financial condition of defaulter borrowers.

(b) To know the causes of over dues, ranking technique was used. Schedule (questionnaire) was distributed to defaulter 
and the bank staff and asked them to give rank for different questions related to nonrepayment of loan according to their priority. It was analyzed through simple tabular and percent analysis.

\section{Results and Discussion}

\section{General Information of Sample Defaulter Borrowers}

Table 1 brings out general information of sample defaulter-borrowers of the study for the year 2014-15. The important variables of the defaulter-borrowers dealt in this study were educational status, family size, size of land holdings, age, estimated income from agriculture, livestock and from other activities and estimated expenditure on agriculture, livestock, old debts and home consumption.

The table depicts that the medium farmer category was the single largest group i.e. 46 per cent of defaulter-borrowers followed by small (36 per cent) and large farmers (18 per cent). From the educational status point of view, the majority of sample defaulterborrowers (60 per cent) were uneducated. Only 40 per cent were educated, out of which only 4 per cent were of educational status of secondary and above level. The average size of family of the defaulters ranged from 6 to 9 members with the average of 7.33 on the overall basis. The largest average size of family was of 9 members in the category of large size group of farmers, while the smallest average size of 6 members was in the category of medium size group. Average age of the defaulter-borrowers ranged between 38 years in the small farmer group category to 41 years in the medium farmer group category with an overall average age of 39.66 years. The composition of size of holding of the defaulter-borrowers ranged from 1.57 ha to 8.24 ha with an overall average size of holding being 4.31 ha. The average estimated income from agriculture was ₹ 123834.16, 205463.68 and 558062.96 for small, medium and large size group of defaulter-borrowers respectively with an overall average income of ₹ 234120.26. The average estimated income from livestock was ₹ 87908.27, 120921.81 and 182561.21 and from off-farm activity were ₹ $13140.75,16446.45$ and 28667.87 for small, medium and large size group of defaulter-borrowers respectively. Thus the average total incomes (from agriculture, livestock and off-farm activity after deducting all its expenses) were ₹ $67133.84,117719.89$ and 352239.57 for small, medium and large size group of defaulter-borrowers respectively. The large size group of defaulters has the highest average total income and that of lowest in case of small farmers group.

\section{Defaulters related questions}

Table 2 and figure 1 shows the different reasons for non-repayment of agricultural loans as reported by the loan defaulters. Majority of defaulters i.e. $98 \%$ reported that they did not pay back the loan amount because of low income generated from crop. $90 \%$ defaulters said that high living expenses reduces their ability to repay the loan. $82 \%$ of sample defaulters were narrated that bank is charging high interest rate which after addition with principal amount adversely affect their ability of repayment of loans. $80 \%$ reported that they get low and unremunerated prices for farm produce which reduces their repayment capacity. 78 and $76 \%$ defaulters reported inadequate amount of loan advanced and thereby assets were not created in reality respectively as the main reason for nonrepayment of loan. The other reasons reported by the defaulters were poor marketing facility for agriculture produce (72\%), absence of linking of credit with marketing (58\%), unexpected financial problems $(48 \%)$ and old debts $(42 \%)$ which reduces their repayment 
capacity. Similarly, 30\% defaulters believed that government waived-off their loans. Likewise, lack of supervision of/ follow up action by the bank staff and unexpected sickness were also narrated by defaulters as other causes of overdues.

\section{Questions Related To Bank Employees}

Besides defaulters, different questions were also asked from the bank employees regarding actual reasons behind nonrepayment of loans by selected defaulter borrowers which were shown in table 3 and figure 2. According to them $88 \%$ defaulterborrowers made large amount of expenditure on social and other religious activities. $86 \%$ of sample defaulters misutilized their loan thereby lead to come under the list of defaulters. They mismanaged the debts. Bank employees also reported that unexpected sickness also reduces their capacity to pay the loan. Similarly, willful defaulters were also there who voluntarily didn't repay the loan. In this case bank employees were reluctant to follow up their own safety.

Table.1 General information of sample defaulter-borrowers

\begin{tabular}{|c|c|c|c|c|c|}
\hline S.N. & Particulars & Small & Medium & Large & Overall \\
\hline 1. & Number of defaulter borrowers & $\begin{array}{c}18 \\
(36)\end{array}$ & $\begin{array}{c}23 \\
(46)\end{array}$ & $\begin{array}{c}9 \\
(18)\end{array}$ & $\begin{array}{c}50 \\
(100)\end{array}$ \\
\hline 2. & $\begin{array}{l}\text { Education Status } \\
\text { (a) Uneducated } \\
\text { (b)Primary } \\
\text { (c) Middle } \\
\text { (d)Secondary and above }\end{array}$ & $\begin{array}{l}8 \\
5 \\
2 \\
1 \\
\end{array}$ & $\begin{array}{l}17 \\
3 \\
2 \\
1 \\
\end{array}$ & $\begin{array}{l}5 \\
2 \\
1 \\
1 \\
\end{array}$ & $\begin{array}{l}30(60) \\
10(20) \\
6(12) \\
4(8)\end{array}$ \\
\hline 3. & Average family size & 7 & 6 & 9 & 7.33 \\
\hline 4. & Average age (Years) & 38 & 41 & 39 & 39.66 \\
\hline 5. & $\begin{array}{l}\text { Average size of land holding } \\
\text { (ha) }\end{array}$ & 1.57 & 3.13 & 10.24 & 4.98 \\
\hline 6. & $\begin{array}{l}\text { Average estimated income } \\
\text { from agriculture }\end{array}$ & 123834.16 & 205463.68 & 558062.96 & 234120.26 \\
\hline 7. & $\begin{array}{l}\text { Average estimated income } \\
\text { from livestock }\end{array}$ & 87908.27 & 120921.81 & 182561.21 & 130463.76 \\
\hline 8. & $\begin{array}{l}\text { Average estimated income } \\
\text { from off farm activity }\end{array}$ & 13140.75 & 16446.45 & 28667.87 & 1941.35 \\
\hline 9. & $\begin{array}{l}\text { Average estimated expenditure } \\
\text { on agriculture }\end{array}$ & 49533.66 & 82885.27 & 203510.18 & 111976.37 \\
\hline 10 . & $\begin{array}{l}\text { Average estimated expenditure } \\
\text { on livestock }\end{array}$ & 47401.13 & 75782.68 & 95207.13 & 72770.31 \\
\hline 11. & $\begin{array}{l}\text { Average estimated expenditure } \\
\text { on home consumption }\end{array}$ & 59439.50 & 62439.50 & 109272.67 & 77050.55 \\
\hline 12. & $\begin{array}{l}\text { Average estimated expenditure } \\
\text { on old debts }\end{array}$ & 1375.05 & 4084.60 & 9062.49 & 16987.32 \\
\hline 13. & Average total income & 67133.84 & 117719.89 & 352239.57 & 179031.10 \\
\hline
\end{tabular}

Figures in parentheses are percent to total 
Table. 2 Causes for non-repayment of agricultural loan reported by defaulters

\begin{tabular}{|c|c|c|c|c|c|}
\hline $\begin{array}{l}\text { Sr. } \\
\text { No. }\end{array}$ & Particulars & Small & Medium & Large & Overal \\
\hline 1. & Low income & $\begin{array}{c}18 \\
(100)\end{array}$ & $\begin{array}{c}23 \\
(100)\end{array}$ & $\begin{array}{c}8 \\
(88.88)\end{array}$ & $\begin{array}{c}49 \\
(98)\end{array}$ \\
\hline 2. & High living expenses & $\begin{array}{c}18 \\
(100)\end{array}$ & $\begin{array}{c}21 \\
(93.30)\end{array}$ & $\begin{array}{c}6 \\
(66.66)\end{array}$ & $\begin{array}{c}45 \\
(90)\end{array}$ \\
\hline 3. & Higher interest rate & $\begin{array}{c}18 \\
(100)\end{array}$ & $\begin{array}{c}20 \\
(86.95)\end{array}$ & $\begin{array}{c}3 \\
(33.33)\end{array}$ & $\begin{array}{c}41 \\
(82)\end{array}$ \\
\hline 4. & $\begin{array}{l}\text { Low and unremunerated } \\
\text { prices for farm produce }\end{array}$ & $\begin{array}{c}17 \\
(94.44)\end{array}$ & $\begin{array}{c}19 \\
(82.66)\end{array}$ & $\begin{array}{c}4 \\
(44.44)\end{array}$ & $\begin{array}{c}40 \\
(80)\end{array}$ \\
\hline 5. & $\begin{array}{l}\text { Inadequate amount of loan } \\
\text { advanced }\end{array}$ & $\begin{array}{c}15 \\
(83.33)\end{array}$ & $\begin{array}{c}19 \\
(82.66)\end{array}$ & $\begin{array}{c}5 \\
(55.55)\end{array}$ & $\begin{array}{c}39 \\
(78)\end{array}$ \\
\hline 6. & $\begin{array}{l}\text { Assets were not created in } \\
\text { reality }\end{array}$ & $\begin{array}{c}16 \\
(88.88)\end{array}$ & $\begin{array}{c}17 \\
(73.91)\end{array}$ & $\begin{array}{c}5 \\
(55.55)\end{array}$ & $\begin{array}{c}38 \\
(76)\end{array}$ \\
\hline 7. & $\begin{array}{l}\text { Poor marketing facility for } \\
\text { agricultural produce }\end{array}$ & $\begin{array}{c}14 \\
(77.77)\end{array}$ & $\begin{array}{c}20 \\
(86.95)\end{array}$ & $\begin{array}{c}2 \\
(22.22)\end{array}$ & $\begin{array}{c}36 \\
(72)\end{array}$ \\
\hline 8. & $\begin{array}{l}\text { Absence of linking of credit } \\
\text { with marketing }\end{array}$ & $\begin{array}{c}11 \\
(61.11)\end{array}$ & $\begin{array}{c}12 \\
(52.17)\end{array}$ & $\begin{array}{c}3 \\
(33.33)\end{array}$ & $\begin{array}{c}29 \\
(58)\end{array}$ \\
\hline 9. & $\begin{array}{l}\text { Unexpected financial } \\
\text { problems }\end{array}$ & $\begin{array}{c}13 \\
(72.22)\end{array}$ & $\begin{array}{c}10 \\
(43.47)\end{array}$ & $\begin{array}{c}1 \\
(11.11)\end{array}$ & $\begin{array}{c}24 \\
(48)\end{array}$ \\
\hline 10. & Old debts & $\begin{array}{c}11 \\
(61.11)\end{array}$ & $\begin{array}{c}8 \\
(34.78)\end{array}$ & $\begin{array}{c}2 \\
(22.22)\end{array}$ & $\begin{array}{c}21 \\
(42)\end{array}$ \\
\hline 11. & $\begin{array}{l}\text { Belief that government } \\
\text { waved-off the loans }\end{array}$ & $\begin{array}{c}9 \\
(50) \\
\end{array}$ & $\begin{array}{c}4 \\
(17.39) \\
\end{array}$ & $\begin{array}{c}2 \\
(22.22) \\
\end{array}$ & $\begin{array}{c}15 \\
(30)\end{array}$ \\
\hline 12. & $\begin{array}{l}\text { Lack of supervision of/ } \\
\text { follow-up action by the bank } \\
\text { staff }\end{array}$ & $\begin{array}{c}5 \\
(27.77)\end{array}$ & $\begin{array}{c}6 \\
(26.08)\end{array}$ & $\begin{array}{c}1 \\
(11.11)\end{array}$ & $\begin{array}{c}12 \\
(24)\end{array}$ \\
\hline
\end{tabular}

Figures in parentheses are percent to total

Table.3 Causes for non-repayment of agricultural loan reported by bank employees

\begin{tabular}{|l|l|c|c|c|c|}
\hline S.N. & \multicolumn{1}{|c|}{ Particulars } & Small & Medium & Large & Overall \\
\hline 1. & $\begin{array}{l}\text { Large amount of expenditure } \\
\text { on social and other religious } \\
\text { activity }\end{array}$ & $\begin{array}{c}17 \\
(94.44)\end{array}$ & $\begin{array}{c}20 \\
(86.95)\end{array}$ & $\begin{array}{c}7 \\
(77.77)\end{array}$ & $\begin{array}{c}44 \\
(88)\end{array}$ \\
\hline 2. & Improper utilization of loan & $\begin{array}{c}17 \\
(94.44)\end{array}$ & $\begin{array}{c}21 \\
(93.30)\end{array}$ & $\begin{array}{c}5 \\
(55.55)\end{array}$ & $\begin{array}{c}43 \\
(86)\end{array}$ \\
\hline 3. & Mismanagement of debts & $\begin{array}{c}16 \\
(88.88)\end{array}$ & $\begin{array}{c}14 \\
(60.86)\end{array}$ & $\begin{array}{c}2 \\
(22.22)\end{array}$ & $\begin{array}{c}32 \\
(64)\end{array}$ \\
\hline 4. & Unexpected sickness & 2 & 5 & 2 & 9 \\
$(11.11)$ & $(21.73)$ & $(22.22)$ & 7 \\
\hline 5. & Willful default & $(16.66)$ & $(13.04)$ & $(11.11)$ & $(14)$ \\
\hline
\end{tabular}

Figures in parentheses are percent to total 
Fig.1 Causes for non-repayment of agricultural loan reported by defaulters

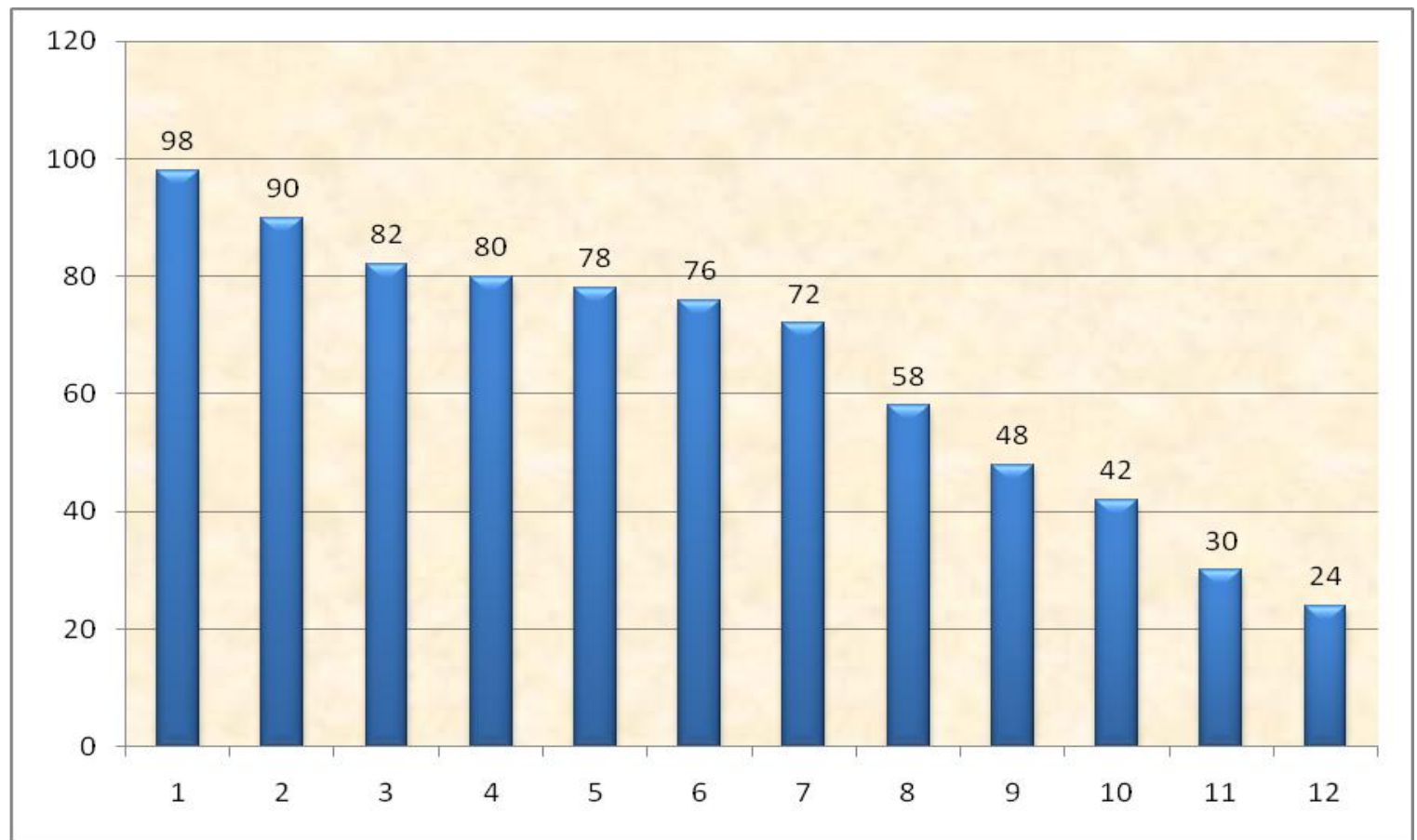

Fig.2 Causes for non-repayment of agricultural loan reported by bank employees

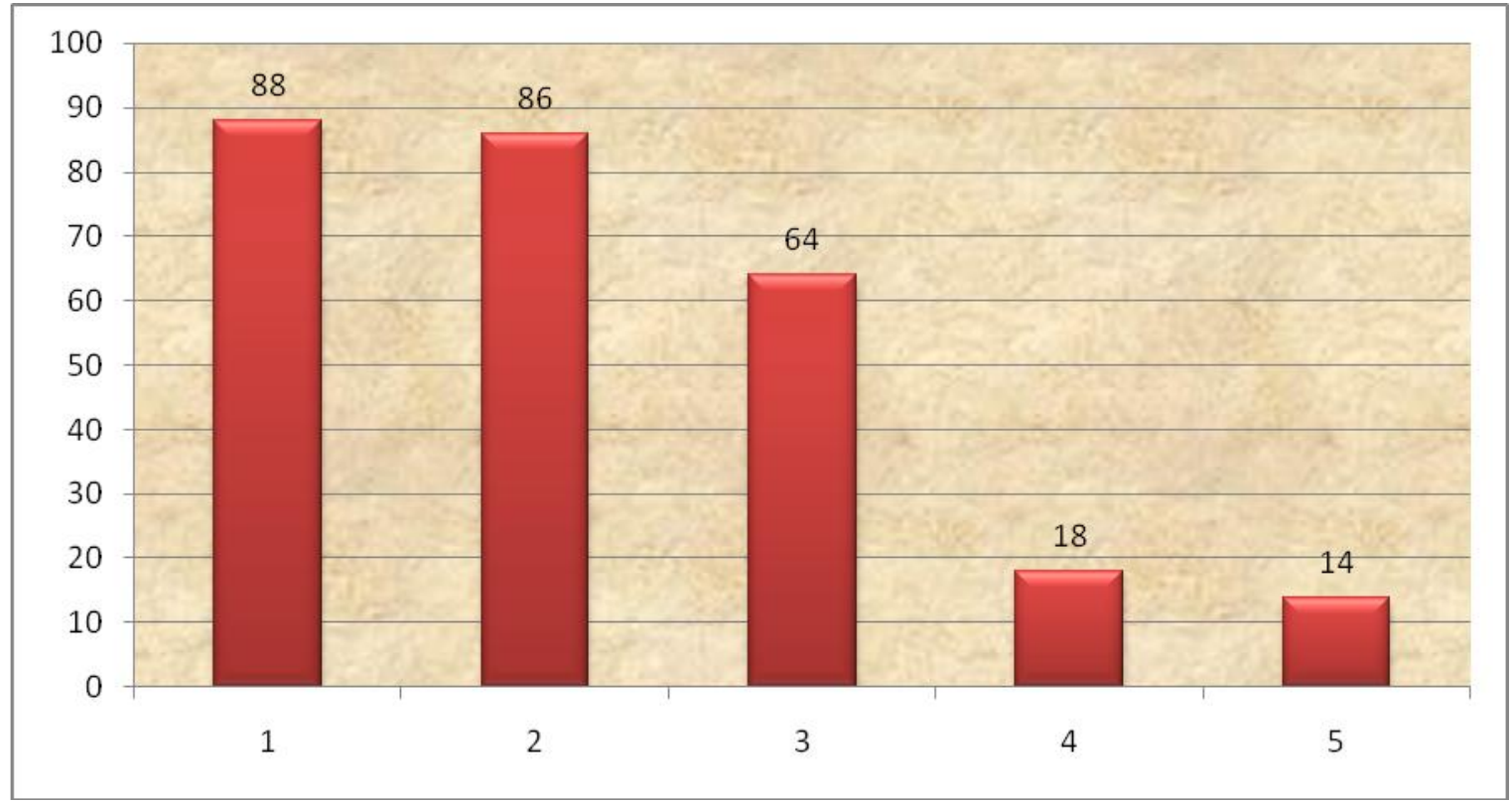

In conclusion, the developing country like India, agriculture credit plays prime role to transform the entire outlook of the economy. However unproductive use of agriculture loan hinders the reduction of poverty and also adversely affects financial institutes. From the above mentioned facts and figures, it can be concluded that low income generated by the use of loan, high living expenditure, large amount of expenditure on social and other religious activities, improper utilization of loan, higher interest rate and low and 
unremunerated prices of farm produce were the main reasons which reduces the capacity of borrowers to repay the loans. These also increase the non-performing loan ratio of bank which resulted in bad functioning of bank.

\section{Recommendations}

Following recommendations are offered to improve and maximize the efficient utilization of agricultural loans so that farmers would get maximize their profit and recovery would also increase:-

- Banks should check the previous repayment behavior of the borrowers before providing loan to them.

- Provide advisory services to the borrowers for efficient utilization and management of agriculture loans they have taken.

- Bank employees should visit the site of borrowers.

- Low and unremunerated prices of agricultural produce associated with the poor marketing facilities resulted in low income to farmer-borrowers. It is therefore, suggested that efforts should be made to establish linkage of credit with marketing through the cooperatives as far as it is possible.

Legal actions should be taken against the willful defaulters.

\section{References}

Afolabi, J.A. 2008. Analysis of loan repayment among small scale farmers in south western Nigeria-A discriminant approach. J. Social Sci., 17(1): 83-88.

Awan, A.G. Nadeem, N. and Malghan, F.S. 2015. Causes of Loan Defaults in
Pakistani Banks: A Case Study of District D.G. Khan. Sci. Int. (Lahore), 27(3): 2593-2597.

Balishter, Chauhan, T.R. 1991. Factors affecting overdues of loans in agriculture - A study in a progressive district of Uttar Pradesh. Indian Cooperative Rev., 28(3): 249-254.

Balishter, Singh, A.K. and Vishwajit. 1994. A study of overdues of loans in agriculture. Indian Co-operative Rev., 31(4): 377-383.

Bhosale, S.R. Dangat, S.B. 1988. A study into the overdues of Co-operative loans in Maharashtra. Indian J. Agri. Economics, 43(3): 420.

Gangwar, A.C. and Aggarwal, K. 1988. Borrowing and repayment performance of farmers pertaining to institutional loans in Kurukshetra district, Haryana. Indian J. Agri. Economics, 43(3): 443.

Gnanadhas, M.E. and Geetha, P. 2009. Repayment of Loan in Employees' Cooperative Thrift and Credit Societies. J. Rural Develop., 28(4): 485 - 490.

Hatai, L.D., Singh, H.P. and Sen, C. and Dixit, R.S. 2005. An economic analysis of agricultural credit and overdues in different regions of Uttar Pradesh. Indian J. Agri. Economics, 60(3): 364365.

Khushro, A.M. 1989. A review of agricultural credit system in India: Report of the agricultural credit reviews committee. Indian J. Agri. Economics, XLVII (2): 287.

Kiran, B. 2015. An Analysis of Agricultural Loan Repayment Performance of Regional Rural Bank: A case study of District Sirsa, India. Int. Res. J. Social Sci., 4(6): 89-92.

Kohansal, M.R. and Mansoori, H. 2009. Factor affecting on loan repayment performance of farmers in Khorasan Razavi Province of Iran. Conference on International Research on Food 
Security, National Resource Management and Rural Development, University of Hamburg, October 6-8, 2009.

Korankye, A.A. 2014. Causes and Control of Loan Default/Delinquency in Microfinance Institutions in Ghana. American Int. J. Contemporary Res., 4(12): 36-45.

Kumar, S. 2005. Problems of overdues in the tribal area of Jharkhand. Indian J. Agri. Economics, 60(3): 358.

Mehmood, Y., Ahmad, M., Anjum, M.B. 2012. Factors Affecting Delay in Repayments of Agricultural Credit; A Case Study of District Kasur of Punjab Province. World Appl. Sci. J., 17(4): $447-451$

Ramasamy, C. and Meskel, R. 1988. Commercial bank lending to agriculture - Some lending issues. Indian J. Agri. Economics, 43(3): 441-442.

Sale, Y.C., Pokharkar, V.G. and Yadav, D.B. 2005. Gaps in requirements, availability and repayment of agricultural credit in Western Maharashtra. Indian J. Agri. Economics, 60(3): 372-373.

Shelke, R.D. Chavan, R.V. and Kamble, S.H. 2016. Performance of Parbhani District Central Cooperative Bank- A Case Study. J. Economic Res. Studies, 1(1): 1-7.
Shivappa, H. 2005. Agricultural credit utilization pattern and its repayment performance of borrowers of Regional Rural Banks in Karnataka - A case study of ChitradurgaGramin Bank. Indian J. Agri. Economics, 60(3): 366.

Sileshi, M., Nyikal, R. and Wangia, S. 2012. Factors Affecting Loan Repayment Performance of Smallholder Farmers in East Hararghe, Ethiopia. Developing Country Studies, 2(11): 205-213.

Singh, A.K., Singh, A.K. and Singh, V.K. 2005. Credit needs, utilization pattern and factors causing overdues in Varanasi district. Indian J. Agri. Economics, 60(3): 385-386.

Singh, N.K. and Dularam. 2007. Disbursement trend, recovery performance and overdues position of agricultural loans in Sriganganagar district of Rajasthan. Indian J. Agri. Economics, 62(3): 390-391.

Singh, R.P. and Sah, A.K. 2005. Repayment performance of borrowers with respect to agricultural loan of Ranchi Kshetriya Gramin Bank: A micro analysis. Indian J. Agri. Economics, 60(3): 396-397.

Singh, S., Kaur, M. and Kingra, H.S., 2007, Institutional agricultural credit in Punjab: Growth and inadequacies. Indian J. Agri. Economics, 62(3): 367368.

\section{How to cite this article:}

Ritu Rathore, Shubham Mishra and Pradeep Kumar. 2017. Factors Affecting Non-Repayment of Agricultural Loan: A Case Study of Rajasthan Marudhara Gramin Bank. Int.J.Curr.Microbiol.App.Sci. 6(4): 1052-1059. doi: https://doi.org/10.20546/ijcmas.2017.604.130 